\title{
İnfodemide Sorumlu Habercilik: Covid-19 Salgınının Haberleştirilmesine Yönelik Yayımlanan İlke ve Rehberler Üzerine Bir Değerlendirme
}

\begin{abstract}
Halil SAÇ ${ }^{\mathbf{1}}$
Aslıhan ARDIÇ ÇOBANER ${ }^{2}$

$\ddot{\mathbf{O} z}$

Kriz ve belirsizlik dönemleri; mezenformasyon, dezenformasyon gibi "enformasyon bozukluğu" olarak değerlendirilen içeriklerin yoğun biçimde dolaşıma sokulduğu dönemlerdir. $\mathrm{Bu}$ içerikler Facebook, Twitter gibi sosyal paylaşım platformları başta olmak üzere enformasyon ekosisteminde hızlı bir biçimde yayılmakta ve infodeminin var olmasına katkı sunmaktadır. Covid-19 salgını sürecinde de salgın ile ilgili içeriklerin enformasyon ekosisteminde dolaşımı; bireylerin ve toplumların sağlığını tehdit edecek davranışların artmasına, sağlık profesyonellerinin çalışmalarının aksamasına ve birey, topluluk veya ülkelerin damgalanmasına ve nefret söylemine maruz kalmasına neden olabilmektedir. $\mathrm{Bu}$ noktada haber medyası, birey ve toplum yararı işlevi açısından kilit bir rol üstlenmektedir. Haber medyası, toplumsal yararı önceliği haline getiren 'sorumlu habercilik' eksenindeki ilkeler ve etik kriterler aracılığıyla bu işlevini gerçekleştirilebilir. Bu çalışmada; Covid-19 salgını sürecinde infodemi ile mücadele için gazeteciler ve haber kuruluşlarına yönelik olarak Pan Amerikan Sağlık Örgütü (PAHO), First Draft, Uluslararası Gazeteciler Ağı gibi uluslararası kuruluşlar ve bazı medya profesyonelleri tarafından yayımlanan çeşitli etik ilkeler ve rehberler incelemiştir. İlgili metinlerden hareketle Covid-19 salgının sorumlu habercilik çerçevesinde nasıl haberleştirileceğine yönelik bir tartışmaya yer vermek ve bir çerçeve çizmek amaçlanmıştır.
\end{abstract}

Anahtar Kelimeler: Sorumlu Habercilik, İnfodemi, Enformasyon Bozukluğu, COVID-19, Haber

\footnotetext{
1 Arş. Gör., Mersin Üniversitesi İletişim Fakültesi, Gazetecilik Bölümü, halilssaac@gmail.com, Orcid ID: 0000-0002-3983-514X

2 Doç. Dr., Mersin Üniversitesi İletişim Fakültesi, Gazetecilik Bölümü, acobaner@gmail.com, Orcid ID: 0000-0002-8210-6938

Bu makaleye atıf için: Saç, H., \& Ardıç Cobaner, A. (2021). İnfodemide Sorumlu Habercilik: Covid-19 Salgınının Haberleştirilmesine Yönelik Yayımlanan İlke ve Rehberler Üzerine Bir Değerlendirme. Aksaray İletişim Dergisi, 3(2), 303-330. doi:10.47771/aid.930415
} 


\title{
Responsible Reporting in Infodemic: A Review on Principles and Guidelines about How the Covid-19 Outbreak is Reported
}

\begin{abstract}
Periods of crisis and uncertainty are the times that "information disorder" such as misinformation, disinformation is intensely put into circulation. Information disorders spread rapidly in the information ecosystem, especially on social networking platforms such as Facebook and Twitter, and cause infodemic. Also during the pandemic Covid-19, circulation of relevant contents in the information ecosystem; cause the behavior to increase and threaten the health of individuals and communities, disrupt the work of health professionals, and can cause individuals, communities, or countries to be stigmatized and exposed to hate speech. At this point, the news media play a key role according to its function of the individual and the public good. News media can realize this function through principles and ethical criteria in the axis of 'responsible reporting' that prioritizes social benefit. In this study; ethical principles and guidelines published by international organizations such as Pan American Health Organization (PAHO), First Draft, International Network of Journalists, and some media professionals for journalists and news organizations to combat infodemic in the process of Covid-19 outbreak are analyzed and from this point forth, it is taken stock of how the Covid-19 epidemic can be reporting with responsibly.
\end{abstract}

Keywords: Responsibly Reporting, Infodemic, Information Disorder, COVID-19, News

\section{Giriş}

Günümüzde sağlık ile ilgili enformasyon hem geleneksel medya (televizyon, radyo, gazete) hem de yeni medya ortamlarından haber medyası aracılığı ile insanlara ulaşmaktadır. Sosyal medya aracılığı ile habere erişim giderek artmakla birlikte, sosyal medyanın kullanıcı türevli doğası bu mecralardaki içeriklerin doğruluğu ve güvenirliğine yönelik endişeleri de arttırmıştır. Covid-19 salgınında da bireylerin krizi anlamlandırmasında enformasyona erişim önemli bir ihtiyaç olmuş, artan sağlık enformasyonu karşısında, enformasyonun doğruluğu ve kalitesi daha da önem kazanmıştır. Zira bu süreçte komplo teorileri ve yalan haber her zamankinden çok yayılırken, bilimsel bilginin akışındaki boşlukları klişeler, önyargılar, spekülasyonlar ve nefret söylemi doldurmuştur (İnceoğlu, 2020). Bu nedenle Covid-19 salgını devam ederken güvenilir haber kuruluşlarından gelen doğrulanmış bilgi daha da önem kazanırken, bireyler 
haber kuruluşlarından gelen enformasyona sosyal medya ve mesajlaşma uygulamalarına göre daha fazla güven duymuştur (Nielsen ve ark., 2020b: 6).

Covid-19 salgını sürecinde kasti bir amaç olmadan aktarılan, doğru olmayan veya yanlış yönlendiren enformasyon olarak tanımlanan mezenformasyon (Wardle ve \& Derakhshan, 2018) ve bireyleri hakikat konusunda yanıltmak amacıyla kasıtlı olarak aktarılan, gerçek olmayan enformasyon olarak adlandırılan dezenformasyon (Fetzer, 2004) gibi içerikler kolaylıkla ortaya çıkıp, kısa sürede geniş kitlelere yayılır hale gelmiştir. Literatürde "enformasyon bozukluğu” (information disorder) olarak da tanımlanan mezenformasyon ve dezenformasyon (Wardle, 2019a) gibi unsurların doğrudan bireyi ve toplumu olumsuz etkileyen yapısının yanında bireylerin fiziksel ve zihinsel sağlığına zarar veren, sağlık kazanımlarını tehdit eden bireysel sonuçların yanı sıra kutuplaştırmayı pekiştiren, nefret söylemini güçlendiren, insan hakları ihlali riskini arttıran ve demokrasiyi tehdit eden toplumsal sonuçları da bulunmaktadır (World Health Organization, 2020a). Covid-19 salgını sırasında sosyal medya gibi ortamlarda çamaşır suyu, saf alkol veya idrar içmenin koronavirüse iyi geldiğine yönelik söylentilerin yayılması sonucunda dünyada yüzlerce kişinin ölmesi (Islam ve ark., 2020) mezenformasyon ve dezenformasyonun bireylerin sağlığına yönelik olumsuz etkisine örnektir. Toplumsal etkilerine örnek ise ilk Covid-19 vakasının görüldüğü ülkenin Çin olmasından dolayı Asya kökenlilere yönelik nefret söyleminin ve damgalamanın artması gösterilebilir. Bunların yanı sıra birçok ülkede artan bilgi kirliği ve panik etkisiyle maske ve dezenfektan gibi ürünlere talep artmış, insanların marketlerde gıda rafları boşalttığı, tuvalet kağıd1, makarna gibi ürünlerin stoklandığı görülmüştür.

Salgın sürecinde mezenformasyon ve dezenformasyon temelli içeriklerin hızlı bir biçimde yayılmasına vurgu yapmak için Dünya Sağlık Örgütü (WHO/DSÖ), ‘enformasyon’ (information) ve ‘epidemi' (epidemic) terimlerinin birleşimine dayanan 'infodemi' (infodemic) terimini kullanmayı önermiştir. İnfodemi; çevrimiçi ve çevrimdışı bilgi bolluğu anlamına gelmektedir ve halk sağlığının tepkisini zayıflatmak, konu ile gündemi değiştirmek için kasıtlı olarak (dezenformasyon) veya kasti bir amaç olmadan (mezenformasyon) yanlış enformasyon yayma girişimlerini de içerisinde barındırmaktadır (World Health Organization, 2020a).

Kriz dönemleri toplumun bilgi gereksiniminin artmasının yanında aynı zamanda gazetecilerin toplumsal menfaatler, etik değerler ve ticari kaygılar arasında kaldığı zamanlardır (Ulmer ve ark., 2009: 315, Demir ve Balc1, 2019: 51). Ancak kâr güdüsü haber kuruluşlarının da sorumlu habercilik yapmalarına engel olabilmektedir. Sorumlu habercilik; enformasyonun kaynaklar ve okuyucular üzerindeki etkisinin göz gönünde bulundurularak aktarım yapılmasıdır (Kwan, 
2019: 7). Bu yönüyle sorumlu habercilik, toplumsal yarar ve bireylere karşı sorumluluk gözeterek gerçekleştirilen enformasyon aktarım pratiği olarak tanımlanabilir. Bu çalışmada esas olarak Covid-19 salgını sürecinde çeşitli sağlık örgütleri ve gazetecilik kuruluşları tarafindan habercilere ve haber kuruluşlarına yönelik hazırlanan ilke ve rehberlerden yola çıkarak, infodemide sorumlu haberciliğin nasıl olması gerektiğine yönelik bir tartışmaya yer vermek ve bir çerçeve çizmek amaçlanmıştır. Bu amaçla çalışmanın ilk bölümünde infodemi ile infodemiyi oluşturan 'enformasyon bozukluğu' kavramlarına değinilmiş ve enformasyon bozukluğu türleri açıklanmıştır. İkinci bölümde sağlıkla ilgili enformasyonun çeşitli mecralarda dolaşımına ve bu bilginin anlaşılabilir ve uygulanabilir bir formata dönüştürülüp aktarılmasına ilişkin 'bilgi aktarımı' kavramına yer verilmiştir. Böylelikle ilk iki bölümde; infodemi ve infodemi sürecinde haberciliğinde içerisinde bulunduğu medya ekosisteminin belirli yönlerine odaklanılarak, Covid-19 sürecinde toplum yararı gözeten haberciliğin öneminin kavranmasına zemin hazırlanmıştır. Üçüncü bölümde infodemide haberciliğin konumuna ve rolüne ilişkin bir değerlendirme yapılmıştır. Son bölümde ise Covid-19 salgınının sorumlu bir biçimde aktarılması için habercilere ve haber kuruluşlarına yönelik hazırlanan ilke ve rehberler incelenmiştir. Bu kapsamda incelenen ilke ve rehberler: (1) Pan Amerikan Sağlık Örgütü’nün (PAHO) hazırladığı “Covid-19 Bilgilendirici Bir Kılavuz: Habercilere Tavsiyeler”, (COVID-19 An Informative Guide: Advise for Journalists), (2) First Draft ekibinden Victoria Kwan, Claire Wardle ve Mandelyn Webb'in ortaya koyduğu "Covid-19 'un Sorumlu Habercilik Ekseninde Aktarılmasına İlişkin Ípuçları" (Tips for Reporting Responsibly on COVID-19) (3) The Washington Post'un sağlı ve bilim editörü Laura Helmuth'un "Mezenformasyon Yaymadan Koronavirüsü Etkili Biçimde Haberleştirmeye Yönelik Ipuçları" (Tipsheet: Covering the Coronavirus Epidemic Effectively without Spreading Misinformation) ve (4) Uluslararası Gazeteciler Merkezi (International Center for Journalists) öncülüğünde kurulan Uluslararası Gazeteciler Ağı'ndan (IJNet) Senami Kojah'ın ortaya koyduğu “Covid-19'un Haberleştirilmesinde Etik Hususlar” (Etical Considerations for Reporting on COVID-19) isimli metinlerdir.

\section{1. İnfodemi ve "Enformasyon Bozukluğu"}

Dünya Sağl1k Örgütü Genel Direktörü Tedros Adhanom Ghebreyesus 15 Şubat 2020'de gerçekleştirilen Münih Güvenlik Konferansı'nda, “Sadece epidemiyle savaşmıyoruz, bir infodemiyle de savaşlyoruz" diyerek içinde bulunduğumuz süreci tanımlamak için 'infodemi' terimini kullanmış ve yaşanılanın sadece bir 'virüs salgını' (epidemic) olmadığını, aynı 
zamanda bir 'enformasyon salgını' ile de mücadele edildiğine dikkati çekmiştir (World Health Organization, 2020b).

Covid-19 salgını sırasında yoğun bir biçimde kullanılmaya başlanan 'infodemi' terimi aslında daha önce 2002 yılında Gunther Eysenbach tarafından kullanılmıştır. Eysenbach, "Infodemiology: The Epidemiology of (Mis)information” isimli çalışmasında, ilk 'infodemiyolojik' çalışmanın 1996'da yayımlandığını belirtmekte ve infodemiyolojinin (infodemiology-information epidemiology) sağlık ile ilgili bilgileri üretim-dolaşım ilişkisi ekseninde inceleyen bir araştırma disiplini olduğunu ifade etmektedir (2002: 763). 'Enformasyon' (information) ve 'epidemi' (epidemic) kelimelerinin birleşimine dayanan 'infodemi' (infodemic), çevrimiçi ve çevrimdışı enformasyon bolluğudur (World Health Organization, 2020a). İnfodemideki söz konusu enformasyon bolluğu, hem teyit edilmiş hem de teyit edilmemiş enformasyonu içermektedir ve bireylerin ihtiyaç duyduğu durumlarda güvenilir kaynaklara erişmesini zorlaştırmaktadır (Pan American Health Organization, 2020b). İnfodemi gerçek olan, doğrulanmış ve yarar amacı güden enformasyonu içerebileceği gibi, gerçeğe dayanan ancak zarar verme gayesi taşıyan (malenformasyon) ve mezenformasyon, dezenformasyon gibi doğrudan yanlış veya yanıltma amacı taşıyan enformasyonu da içerebilmektedir. İnfodeminin bu heterojen yapısı bireylerin fiziksel ve ruhsal sağlığına zarar verebilmekte, halk sağlığını korumak için alınan önlemlerin etkinliğini azaltabilmekte ve damgalama gibi olumsuz toplumsal olgulara neden olabilmektedir (World Health Organization, 2020a).

İnfodeminin ortaya çıkmasında ve pekişmesinde çeşitli biçimde zedelenmiş, çarpıtılmış veya amacı farklılaşmış enformasyon da etkilidir. Wardle, bu eksende değerlendirilebilecek enformasyon biçimlerinin tasvirinde kullanılan mezenformasyon, dezenformasyon ve malenformasyon kavramlarını 'enformasyon bozukluğu' (information disorder) ${ }^{3}$ şeklinde genellemiş ve bu üç kavramı bir enformasyon bozukluğu türü olarak ele almıştır (2019a: 12). Mezenformasyon, manipülatif veya kötü niyet olmaksızın üretilen ve/veya dolaşıma sokulan yanlış enformasyondur (Berger, 2018: 7). Mezenformasyon hakikati yansıtmadığı için dolaşımdayken salt yanlış olmakla sınırlı kalmaz, aynı zamanda yanlış yönlendirici de olabilir (Wardle ve Derakhshan, 2018: 44). Losee, mezenformasyonun sadece eksik bilgiden de meydana gelebileceğini (akt. Karlova ve Fisher, 2012: 3), Karlova ve Lee ise belirsiz/şüpheli/muğlak enformasyonun da mezenformasyona yol açabileceğini belirtmiştir

\footnotetext{
3 "Information disorder" terimi, bu çalışmada dahilinde "enformasyon bozukluğu" olarak çevrilmiştir.
} 
(akt. Karlova ve Fisher, 2012: 4). Bireyler yaydıkları enformasyonun doğruluğuna inanarak mezenformasyon içeriğini tekrar ve tekrar dolaşıma koyabilmekte ve bu durum infodeminin büyümesinde rol oynamaktadır (Wardle ve Derakhshan, 2018: 44).

Dezenformasyon ise kasıtlı ve belli bir amaca yönelik olarak, yanlış olduğu bilinerek dolaşıma konulan enformasyondur (Wardle ve Derakhshan, 2018: 44). İngilizce'de 'deliberately false information' yani 'kasıtlı olarak yanlış enformasyon anlamına gelen dezenformasyon, kasti bir amaç güden yanlış enformasyon olmanın yanı sıra Fallis (2009)'in de belirttiği biçimde 'yanıltıcı' olmayı da içerisinde barındırabilir (Fallis, 2009'dan akt. Karlova ve Fisher, 2012: 4). Karlova ve Fisher'a göre aldatıcılığın ardındaki spesifik sebepler net bir biçimde bilinememekle birlikte; dezenformasyon siyasi, kültürel ve toplumsal nedenlerden kaynaklanabilmektedir. Aldatıcı bir karaktere sahip olabilen dezenformasyon, eksik bilgi verilerek de belirebilir (Karlova ve Fisher, 2012: 4). Wardle (2019a: 8) ise dezenformasyonun üç unsur ile motive edildiğini belirtir. Bunlar ise (1) para kazanmak, (2) siyasette etki sahibi olmak, (3) bu amaçlara ulaşmak için çeşitli karışıklıklar/olumsuzluklar yaratmaktır. Bu amaçlar için belirli aktörler tarafından üretilen dezenformasyon dolaşıma girdikten sonra, haber medyasında veya sosyal medyada herhangi bir kasıt olmaksızın tekrar dolaşıma sokulduğunda ise mezenformasyona dönüşmektedir (2019a: 8).

İnfodemiye katkı sunan bir başka kavram da malenformasyondur. Malenformasyon, gerçeğe dayalı bilgilerin bir kişi, kurum/kuruluş veya ülkeye zarar vermek amacıyla kullanılmasıdır (Wardle ve Derakhshan, 2018: 44). Latince'de 'kötücül' anlamına gelen malenformasyon kötü amaç ekseninde enformasyonun sızdırılmasını, nefret söylemini veya herhangi bir kişi-topluluğa yönelik tacizi içerebilmektedir (Silsüpür, 2018). Malenformasyon, gerçeğe dayanan enformasyonun yeniden yapılandırılmış hali olup (Brennen ve ark.'dan akt. Baines ve Elliott, 2020: 14) potansiyel olarak zarar verme amacı taşımakta ve açık biçimde dolaşımı bireylere ve kurumlara zarar verebilmektedir (Burbules, 1997: 113'den akt. Santos-D'amorim ve de Oliveira Miranda, 2021: 8). Malenformasyon gerçek veya tüzel öznelere yönelik zarar verme güdüsünde olduğu için içinde damgalama veya nefret söylemini açık veya dolaylı biçimlerde barındırabilir. 


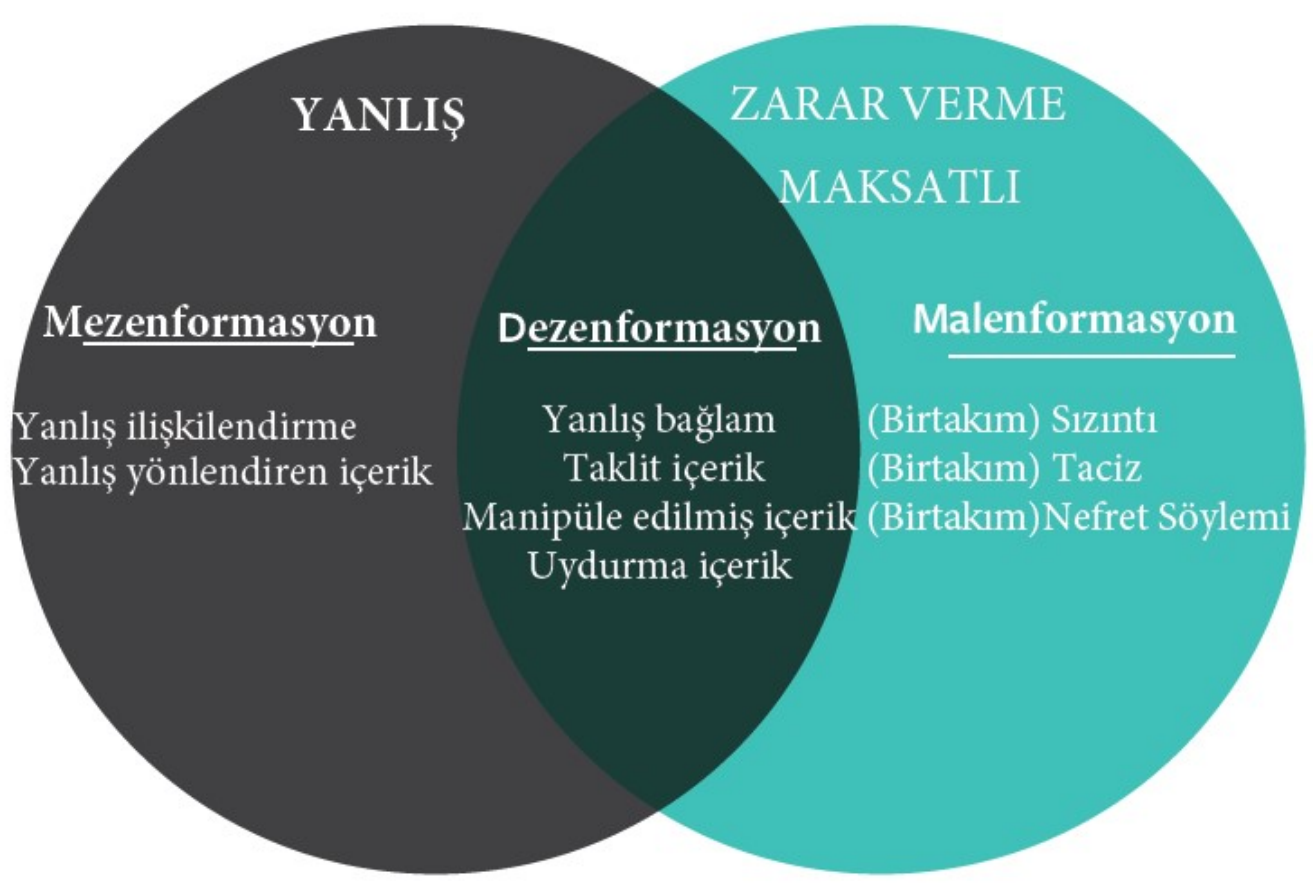

Şekil-1: Enformasyon Bozukluğu [(Kaynak: Wardle ve Derakhshan, 2018: 44; Wardle, 2019b; Wardle, 2019a: 9].

Şekil-1'de enformasyon bozukluğunun üç türünün (mezenformasyon, dezenformasyon ve malenformasyon) birbiri ile ilişkisi ve kesiştikleri alanlara yer verilmiştir (Wardle ve Derakhshan, 2018: 44). Wardle (2019a) ise enformasyon bozukluğu kapsamında yer alan dezenformasyon, mezenformasyon ve malenformasyonun içerisinde bulunduğu karmaşık ekosistemin daha kolay kavranabilmesi için yedi kategori ve zarar düzeyi belirlemiştir. Bunlar (1) Uydurma içerik, (2) Manipüle edilmiş içerik, (3) Taklit içerik, (4) Yanlış bağlam, (5) Yanlış yönlendirici içerik, (6) Yanlış ilişkilendirme ve (7) Hiciv veya parodidir (Şekil-2). 


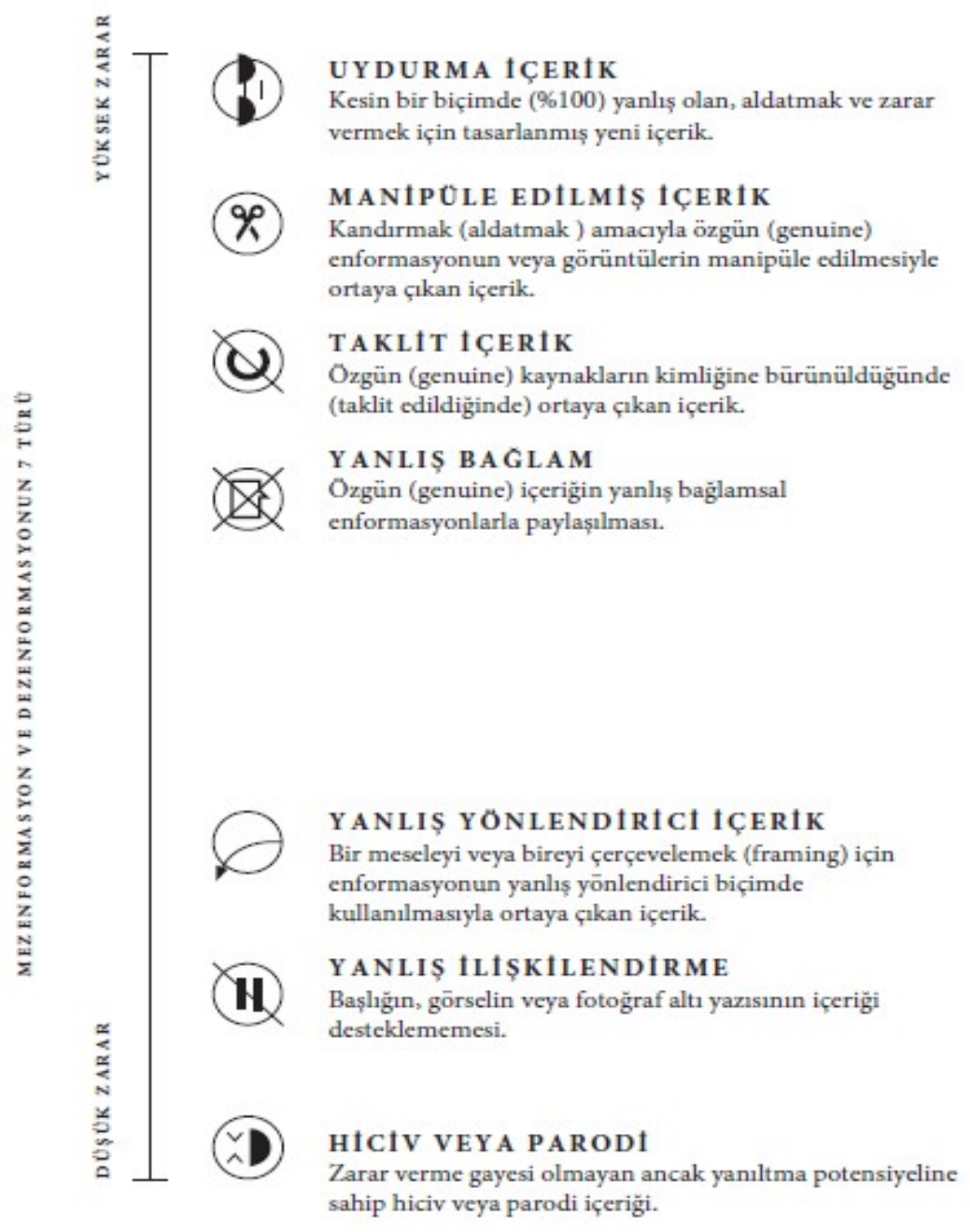

Şekil-2: Mezenformasyon ve Dezenformasyonun Yedi Türü [Kaynak: Wardle, 2019a: 10-11]. Bu kapsamda sıkça kullanılan bir başka kavram ise yine gerçeği yansıtmayan veya gerçeğin çarpıtılmış, zedelenmiş halini tanımlamak için kullanılan 'yalan haber' (fake news)' dir. Wardle ve Derakhshan, 'yalan haber' teriminin -herhangi bir biçimde- iktidarda bulunan bireylerin hoşlarına gitmeyen haberleri baltalamak için veya politize ederek haber medyasına karşı kullanılan bir terim olduğuna dikkat çekmekte, bu nedenle 'yalan haber' yerine dezenformasyon ve mezenformasyonun kullanımını tercih ettiklerini belirtmektedir (2018: 43). Allcott ve Gentzkow sahte ya da yalan haberi kasıtlı ve doğrulanabilir şekilde yanlış olan ve okuyucuları yanlış yönlendirebilecek haber metinleri olarak tanımlarken (2017: 213), Klein ve Wueller ise bilerek veya kasıtlı olarak yanlış ifadelerin çevrimiçi yayınlanması olarak tanımlamaktadır (2017). Son tahlilde Lazer ve ark.'na göre sahte haber, mezenformasyon ve dezenformasyon gibi diğer bilgi bozuklukları ile benzerlik taşımaktadır (2018: 1094). Hali hazırda, 'haber' gerçekliği içerisinde barındıran bir kavram olduğundan 'yalan' nitelemesiyle birlikte kullanımı bir oksimoron yaratmaktadır (Uzun, 2020: 53). Bu nedenle çalışmada, 
"dezenformasyon", "mezenformasyon", malenformasyon ve "yalan haber" (fake news) kavramları, "enformasyon bozukluğu” başlığında kullanılmıştır.

\section{2. İnfodemide Enformasyonun Dolaşımı ve Bilgi Aktarımı "Knowledge Translation"}

Enformasyon bozukluğu türlerinin geniş kitleler arasında yayılarak infodemiye yol açmasında enformasyonun üretim ve dolaşımında görev alan medya dahil tüm faktörler kilit bir noktada durmaktadır. Mezenformasyon ve dezenformasyonun dijital ve yüz yüze iletişim aracıllı̆̆ıyla insanlar arasında bir epidemi gibi yayılması, bireylerin enformasyona ihtiyaç duyduğu zamanlarda güvenilir kaynak bulmayı zorlaştırarak infodemiye yol açmaktadır (Tangcharoensathien ve ark., 2020: 2). Enformasyon ekosisteminin yüz yüze iletişimden sosyal paylaşım platformlarına kadar geniş ve iç içe geçmiş bir yapıya sahip olması, mezenformasyon ve dezenformasyon gibi enformayon bozukluğu türlerinin yayılım hızını da arttırmakta ve infodeminin yayılımını kolaylaştırmaktadır. Eysenbach (2020), infodeminin “(1) bilim, (2) politika ve sağlık hizmeti uygulayıcıları, (3) haber medyası ve (4) sosyal medya” şeklinde sıralanan dört aktör/katman arasındaki enformasyon akışıyla ilişkili bir kriz olduğuna dikkat çekmekte ve dört katman arasındaki enformasyon akışını 'Enformasyon pastası' olarak adlandırdığı aşağıdaki modelle açıklamaktadır. 

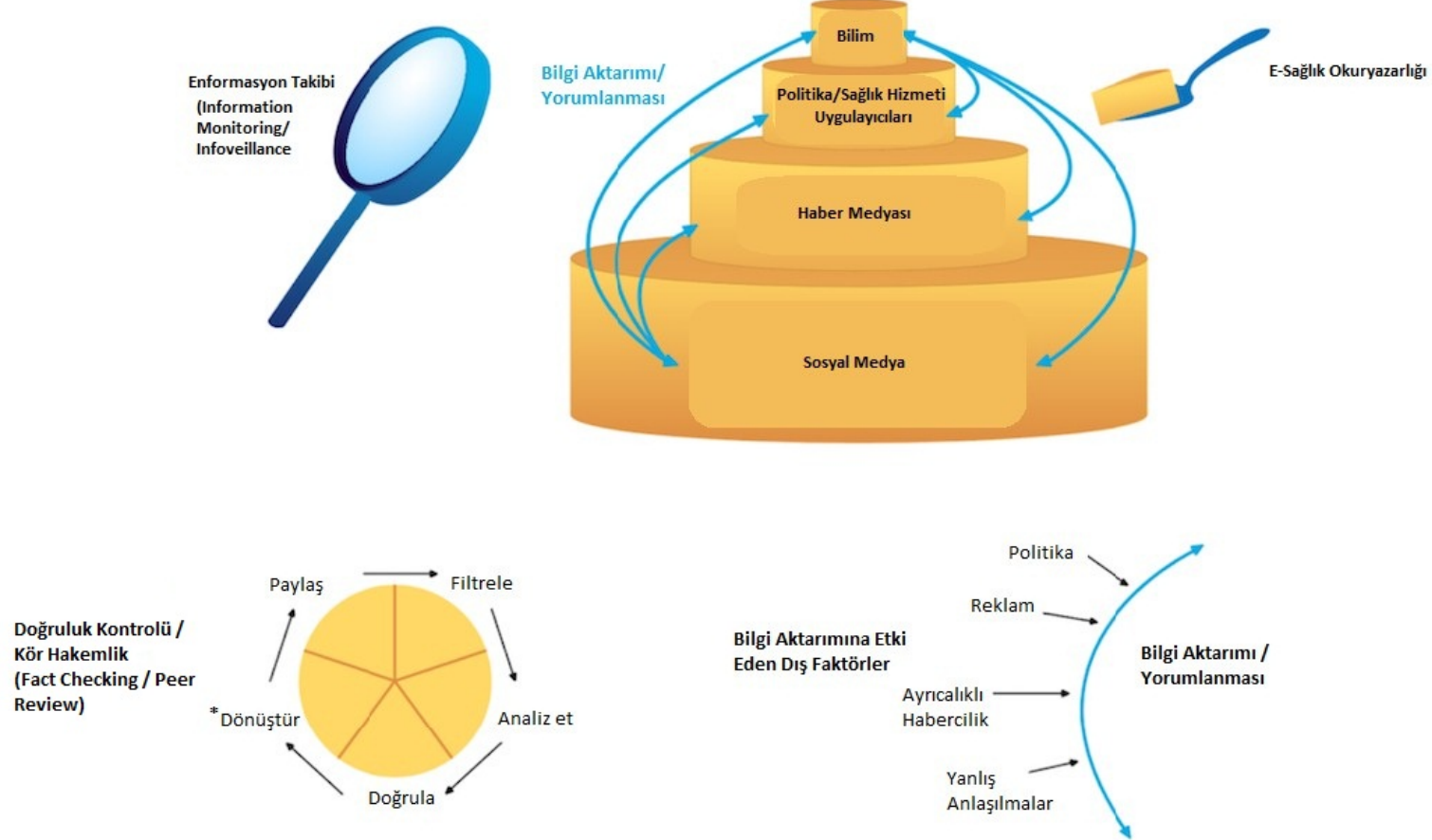

* Asıl modelde "transform" sözcüğü kullanılmıştır. Bu açıdan

"dönüştürmek" sözcüğü "anlaşıılır kılmak" şeklinde de çevrilebilir

Şekil 3: Enformasyon Pastas1 Modeli [Eysenbach, 2020]

Enformasyon pastası modeline göre bilim tarafından üretilen, titiz ve seçici bir süreç sonucunda ortaya çıkan 'bilgi' (knowledge), tüm katmanların en üstünde yer alıp, en küçük dilimini oluştururken; en alt katmanda sosyal medyada tekil kullanıcılar tarafından da çok miktarda üretilip dolaşıma konulan ve teyit/filtre işlemine tabi tutulmamış enformasyon bulunmaktadır.

Modelde ayrıca katmanlar arasında gerçekleşen 'bilgi aktarımı' (knowledge translation) ve 'enformasyon akışı 'na (information flow) dikkat çekilmektedir (Eysenbach, 2020). Türkçe'de 'bilgi yorumlanması' veya 'bilgi aktarımı' olarak ifade edilebilecek olan 'knowledge translation' en temel haliyle; sağlık alanında üretilen bilimsel bilginin, çeşitli mesleki ve toplumsal tabakalara anlaşılabilir/kullanılabilir/uygulanabilir hale getirilerek aktarılmasıdır. Ayrıca sadece bilginin üretimini ve salt bir biçimde aktarımını değil, anlaşılır ve uygulanabilir bir formata dönüştürülüp aktarılmasını da içermektedir (Eysenbach, 2020).

Bilgi aktarımı aynı zamanda bilgiyi uygulamaya geçirmekle de ilgili bir kavramdır (Graham ve ark.'dan akt. Straus ve ark., 2009: 165-166). Bu yönüyle bilgiyi üreten araştırmacılar ile onu 
kullananlar ve ondan yararlananlar başta olmak üzere sağlık alanındaki politika yapıcılar, sağlık hizmeti uygulayıcıları, bilginin aktarımını sağlayan medya ve kitle iletişim araçları ve eğitimciler gibi birçok aktör arasındaki etkileşimli sürece dikkat çekilmektedir (Sudsawad, 2007: 2). Salgınlar gibi halk sağlığının ve bilhassa koruyucu/önleyici sağlık unsurlarının kilit rol oynadığg dönemlerde üretilen bilimsel bilginin çeşitli biçimlerde (sağlık alanında politika yapanlar, haber medyası, sosyal medya vb. aracılığıyla) toplumun tamamına aktarılması önem kazanmaktadır. Bu noktada bilgi aktarımı sadece bilginin bir noktadan başka bir noktaya taşınmasını değil bilginin özü bozulmadan ve kullanışlı bir biçimde çeşitli mesleki ve toplumsal kesimlere taşınmasına da vurgu yapmaktadır. Bu yönüyle Covid-19 salgını sürecinde bilgi aktarımı, tıbbi bilgilerin kitlelere haber medyası ve diğer mecralar aracılığıyla anlaşılır ve uygulanabilir bir biçimde aktarılması olarak açıklanabilir.

Eysenbach bilgi aktarımını, bilginin bir katmandan ötekine aktarılırken bilgiyi bozacak faktörlerin en aza indirilmesi anlamında kullanmaktadır. Eysenbach'a göre, bilginin mezenformasyona dönüştüğü ana mekanizma siyasi, ticari ilişkiler, seçici habercilik pratikleri ve yanlış anlaşılmalar gibi dış faktörlerden etkilenen katmanlar arasındaki geçiş sürecidir (2020). Bilimsel bilgi aktarım sürecinde çeşitli dış etmenler nedeniyle özünden farklılaşarak alt katmanlara inebilmektedir. Sağlık alanındaki bilimsel bilginin belli bir terminoloji bağlamında üretilmesi, bu tür bilginin toplumun tüm tabakalarınca doğrudan anlaşılması önünde set oluşturmaktadır. Covid-19 özelinde sağlık ile ilgili bilginin anlaşılır kılınarak geniş kitlelere aktarılmasında haber medyası ve sosyal medya kilit bir noktada durmaktadır. Keza salgın sürecinde bireylerin büyük çoğunluğu enformasyon ihtiyacını karşılamak için sosyal medyayı, arama motorlarını, video paylaşım sitelerini ve mesajlaşma uygulamalarını kullanmıştır (Nielsen ve ark., 2020a: 3). Koronavirüsle ilgili koruyucu sağlık bilgilerinin haber medyası ve sosyal medyada doğru bir biçimde paylaşılması birey ve toplum sağlığı için kilit bir rol oynamaktadır. Salgın esnasında bireyler, çeşitli enformasyon kaynaklarından enformasyon bozukluğu denilen dezenformasyon ve mezenformasyon gibi içeriklere sıkça maruz kalmakta, bu gibi içeriklerin geniş kitlelere yayılması ise infodemiyi şiddetlendirmektedir.

\section{3. İnfodemide Enformasyon Kaynağı Olarak Haber Medyası ve Sosyal Medya}

Covid-19 salgını insanların salgın öncesinde kolayca ulaşabildikleri kaynaklara sosyal mesafe ve tecrit gibi uygulamalar nedeniyle erişimini güçleştirirken, aynı zamanda aile, iş ve çalışma ortamları gibi gündelik yaşamın birçok yerleşik ilişki biçimini de yeniden düzenlemiştir. $\mathrm{Bu}$ "yeni normal" durum insanları bir yandan virüsten kendilerini korumaya bir yandan da bu değişimlere ayak uydurmaya zorlamıştır. Bu süreçte geleneksel haber medyası ve online haber 
mecraları bireylerin ve toplumların temel başvuru kaynağı haline gelmiştir. Böylesi küresel ölçekte bir halk sağlığı krizini anlamak ve ona uyum sağlamak amaciyla televizyon, radyo, gazete gibi geleneksel kitle iletişim araçlarının yanında internet haber medyası ve sosyal medya da yoğun biçimde kullanılmıştır.

Sosyal medyanın tüm kullanıcılarına enformasyon üretim imkânı tanıması, enformasyon bozukluğunun da kolaylıkla üretilip dolaşıma sokulmasına yol açmıştır. Eysenbach'ın (2020) modelinde belirttiği şekliyle enformasyon akışı ile sadece bireyle değil, diğer aktörler (bilimsel bilgi üretenler, sağlık alanında politika yapıcılar ve sağlık hizmeti uygulayıcıları ve haber medyası) de kullanıcılar olarak sosyal medyada içerik üretimine katılmıştır. Bu durum, sosyal medyayı tüm aktörlerden gelen içeriklere açık bir havuz olarak haline getirmiştir. Bireyler, enformasyona en ihtiyaç duydukları zamanlarda enformasyon yığınları arasında hangisinin hakikat hangisinin enformasyon bozukluğu olduğunu belirlemekte zorlanabilmiştir.

Dezenformasyon ve mezenformasyon gibi enformasyon bozukluğunun başta sosyal medya olmak üzere medya ekosisteminin tümüne yayılması ve bireylerin sosyal medyadan edindikleri enformasyona güvensizliklerinin artması, haber medyası gibi daha kurumsal kimliğe sahip enformasyon kaynaklarının önemini arttırmaktadır. Nielsen ve ark., haber kuruluşlarının Covid-19 ile ilgili enformasyon ihtiyacını karşılamada önemli bir kaynak olduğunu belirtmekte (2020a: 9), Fletcher ve ark. ise salgın sürecinde haber tüketiminin öncesine nazaran arttığına dikkati çekmektedir (2020: 6-7).

Haber medyası, infodeminin egemen olduğu ortamda gerek birey ve toplum sağlı̆̆ının korunmasında önemli bir role sahiptir. Koronavirüs özelinde, haber medyası; sağlık alanındaki bilimsel yayınlardan çeşitli çıkarımlar yapmak, sağlık uzmanlarıyla çeşitli söyleşi-röportajlar gerçekleştirmek, sağlık alanındaki karar vericilerle doğrudan (söyleşi, röportaj gibi) veya dolaylı (basın açıklamaları) olarak görüş almak gibi yollarla elde ettiği bilgileri kitlelere aktarmaktadır. Bu süreci Eysenbach'ın modeline uyarlarsak bilimsel bilginin uzmanlardan çeşitli sağlık otoritelerine, daha sonra da haber medyasına ulaşması bilginin yıpranmasını ve bir biçimde özünden farklılaşmasını beraberinde getirebilmektedir. $\mathrm{Bu}$ noktada, Eysenbach'in bilimsel bilginin kitleler için uygulanabilir bir formata dönüştürülüp aktarılması için kullandığı 'bilgi aktarımı' kavramı, haber medyası özelinde 'dolayımlama' kavramına dönüşmektedir. Dolayımlama; medya içeriği oluşturulurken bilginin enformasyona, olayın öyküye, kaynağın aktöre dönüştüğü; bu içeriklerin medya tüketicisi için en anlaşılır 
formata büründürüldüğ̈̈ bir süreçtir ${ }^{4}$ (Çağlar, t.y.: 9-10). Dolayımlama sağlık ile ilgili bilgilerin aktarılmasında çeşitli aksaklıklara da yol açabilmektedir. Örneğin, sağlık alanında yetkin olmayan bir muhabirin söz konusu otoritelerin aktardığı bilgileri yanlış algılaması ve mezenformasyon haline dönüştürerek aktarması bilginin aşınması ile sonuçlanabilmektedir. Gazeteciler sağlık uzmanları veya yetkililerden edindiği bilgileri anlaşılır kılarak kitlelere aktarabilir, sosyal medyada yayılan ve birey sağlığına zarar verebilecek dezenformasyon ve mezenformasyon içerikleri teyit ederek yanlış bilinenlerin yerine doğrusunu koyabilir. Dolayısıyla konu sadece medya ile ilgili bilgi üretimi ve dağıtımı etkinlikleriyle sınırlı değildir; haber kuruluşları aynı zamanda sosyal medya mecralarında yayılan bilginin güvenirliğini de arttırabilir. Bu yönüyle haber medyasının enformasyon ekosistemindeki diğer aktörler arasında bir kesişim noktasında olduğu söylenebilir.

İnfodemi sonucunda, koronavirüse ilişkin enformasyon bozukluğunun geniş kitlelere yayılması, bireylerin sağlıklarını olumsuz yönde etkileyecek kararlar almalarına neden olmuştur. Bu nedenle doğrulama/teyit bu tür içeriklerle mücadele edilmesi açısından anahtar rol oynaktadır. Mezenformasyon ve dezenformasyon içeriklerin sosyal medyada ve haber medyasında yayılımına engel olmak için çeşitli doğruluk kontrolü (fact checking) araçları kullanılmaktadır. Örneğin DSÖ, edindiği enformasyona dair şüpheleri olan bireylerin -doğruluk kontrolü yapan kuruluşların birleştiği bir çatı kuruluş olan- International Fact Checking Network (Uluslararası Doğruluk Kontrolü A ğı) aracılığıyla teyit işlemi gerçekleştirebileceğini ve böylelikle infodeminin azalabileceğini söylemiştir (World Health Organization, 2020c). Türkiye'de de Yalansavar, Malumatfuruş, Teyit.org, Fact-Checking Turkey, Günün Yalanlarl, Doğruluğu Ne gibi (Akyüz, 2020) doğruluk kontrolünün sağlanmas1 amaciyla faaliyet gösteren kuruluş ve girişimler Covid-19 sürecinde daha görünür olmuştur. Covid-19 sürecinde doğrulama platformlarının hem kullanıcı sayıları hem de doğruluk kontrolü yapılan içerikler içerisinde Covid-19 salgını etrafındaki iddiaların ve yanlış bilgilerin oranı artmıştır (Uzunoğlu ve Uyar, 2021).

Haber medyası çeşitli enformasyon doğrulama araçları kullansa da içeriklerinin daha fazla okunması için clickbait (tık yemi başlık) kullanılması, haberlerin sağlık terminolojisine hâkim olmayan muhabirler tarafindan yapılması, Covid-19 ile ilgili bilimsel bilgilerin politika yapıcılar tarafından aktarılması sonucunda bu bilgilerin bir biçimde farklılaşması gibi çeşitli faktörler infodeminin pekişmesinde etkili olabilmektedir. Bilimsel bilginin bu dolayımlanması

\footnotetext{
4 Dolayımlama iki aşama olarak görülmekle birlikte, burada söz konusu aşama ilk aşamadır. Dolayımlamanın ikinci aşaması, içeriğine medya kuruluşunun yayın kimliği, yayın politikası gibi unsurlar ekseninde şekil verilmesidir (Çağlar, t. y.: 9-10).
} 
sürecinin yanı sıra haber medyasının baskın bir biçimde kâr odaklı faaliyet sürdürmesi, temel gelir kaynağının daha çok tüketilmeye bağlı reklam olması "kamu yararı ilkesinin ihlal edilmesine" (Taylan ve Ünal, 2017: 28) ve ticari çıkarların ön planda tutulmasına sebep olabilmektedir.

Salgın sırasında yaygınlaşan infodemi, salt bireylerin sağlıklarını herhangi bir biçimde etkileyen enformasyonların yayılımı kapsamamakta, aynı zamanda ciddi toplumsal etkiler de yaratmaktadır. Covid-19 esnasında ortaya çıkan belirgin bir etki olarak "damgalama" gösterilebilir. "Damgalanma (stigmatization) kavramı sahip oldukları farklı bir özelliğe yönelik kişi ya da grubun haksız muamelesi olarak tanımlanmaktadır” (Ertem, 2020: 135). Islam ve ark., infodeminin toplumsal etkilerine odaklandıkları çalışmada damgalamayı; bir kişinin hastalığ1, -virüse- maruz kalması, seyahat geçmişi veya etnik kökeni sebebiyle doğrudan veya dolaylı olarak etiketlendiği/damgalandığı toplumsal bir olgu olarak ifade etmekte, sağlık çalışanları ile Asya kökenli bireylerin damgalanmasına dikkat çekmekte (2020: 1622-1623) ve sosyal medyada dolaşan çeşitli örnekler sunmaktadır: "Çinliler medeniyetsizdir", "Çinliler biyo-teröristtir”, “Tüm hastalıklar Çin kökenli”, "Virüsünü kendine sakla kirli Çin” (Islam ve ark., 2020: 1626). Bu gibi damgalamaların sosyal medya ve/veya haber medyası aracılığıyla yayılması, belli kesimlere yönelik nefret söylemini artırmakta ve nefret suçlarını tetikleyebilmektedir.

Görece daha güvenilir bir enformasyon kaynağı olarak görülebilecek haber medyasının (Flatcher ve ark., 2020), işleyişinde ortaya çıkabilecek sorunların giderilmesinde etik ilkeler önemli bir rol oynayabilmektedir. Covid-19 salgını sırasında da çeşitli kurum, kuruluş veya organizasyon tarafından haberlerin sorumlu bir biçimde aktarılması için habercilere ve haber kuruluşlarına yönelik birçok ilke ve rehber hazırlanmıştır. Çalışmanın bu bölümünde bu etik ilkeler gözden geçirilmiş ve Covid-19 salgını sürecinde infodemide sorumlu haberciliğin nasıl olması gerektiğine dair bir çerçeve sunulmuştur.

\section{Covid-19 Salgınında Sorumlu Habercilik ve Salgının Haberleştirilmesine Yönelik} Tavsiyeler

Küresel koronavirüs salgınında haberciler, bireylerin ve toplumun sağlığını ve ortaya çıkabilecek toplumsal sonuçları göz önünde bulundurup, toplumsal yükümlülükler ekseninde hareket ederek gerek salgının gerek infodeminin kontrol altına alınmasında kilit bir noktada durmaktadır. Haber kuruluşları, üniversiteler, platformlar ve sivil toplum kuruluşlarından oluşan ve web kaynaklı içeriğin nasıl bulunacağı, doğrulanacağı ve yayımlanacağı gibi konularda etik rehberlik sağlamayı amaçlayan First Draft'tan Victoria Kwan'a göre sorumlu 
habercilik; habercilerin çalışmalarının kaynaklar, konular ve okuyucular üzerindeki etkisinin, dijital alanda söylediklerinin ve paylaştıklarının -yayımlanmış olmasa dahi- sonuçlarının ve kirlenmiş enformasyon ekosisteminde medyanın oynadığı rolün farkında olunması demektir (2019: 7-8). Burada incelenen tüm metinlerin ortak ekseninde sorumlu habercilik; enformasyonun kaynaklar ve okuyucular üzerindeki etkisinin ve ortaya çıkabilecek olası sonuçların göz önünde bulundurularak, toplumsal yarar ve sorumluluk ekseninde enformasyon aktarımının yapılması veya olumsuz sonuçlara yol açabilecek enformasyonun aktarılmaması olarak tanımlanabilir. Bu süreçte gazetecilik ile ilgili bazı kurum, kuruluş ve organizasyonlar salgının haberleştirilmesinde toplum yararının gözetilmesine ve sorumlu gazeteciliğe sıklıkla vurgu yaptıkları çeşitli ilkeler ve açıklamalar yayımlamışlardır. Çalışmanın bu bölümünde Covid-19'un haberleştirilmesinde dikkat edilecek noktalar aşağıda yer alan rehber ve ilkelere atıf yapılarak çeşitli başlıklar altında açıklanacaktır.

\begin{tabular}{|c|c|}
\hline Yayımlayan Kişi/Kurum & 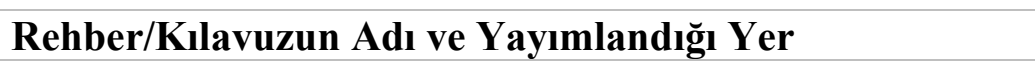 \\
\hline $\begin{array}{l}\text { Pan Amerikan } \\
\text { Örgütü (PAHO) }\end{array}$ & $\begin{array}{l}\text { "Covid-19 Bilgilendirici Bir K1lavuz: Habercilere } \\
\text { Tavsiyeler" (COVID-19 An Informative Guide: Advise for } \\
\text { Journalists) Erişim Adresi: } \\
\text { https://iris.paho.org/bitstream/handle/10665.2/52392/PAHO } \\
\text { CMUPACOVID-1920003_eng.pdf?sequence=1\&isAllowed } \\
=y\end{array}$ \\
\hline $\begin{array}{l}\text { First Draft Ekibi- Victoria } \\
\text { Kwan, Claire Wardle ve } \\
\text { Mandelyn Webb }\end{array}$ & $\begin{array}{l}\text { "COVID-19'un Sorumlu Habercilik } \\
\text { Ekseninde } \\
\text { Aktarılmasına İlişkin İpuçları" (Tips for Reporting } \\
\text { Responsibly on COVID-19) Erişim Adresi: } \\
\text { https://firstdraftnews.org/latest/tips-for-reporting-on-covid-1 } \\
\text { 9-coronavirus-and-slowing-the-spread-of-misinformation/ }\end{array}$ \\
\hline $\begin{array}{l}\text { The Washington Post'un } \\
\text { sağlık ve bilim editörü Laura } \\
\text { Helmuth }\end{array}$ & $\begin{array}{l}\text { "Mezenformasyon Yaymadan Koronavirüsü Etkili Biçimde } \\
\text { Haberleştirmeye Yönelik İpuçları" (Tipsheet: Covering the } \\
\text { Coronavirus Epidemic Effectively without Spreading } \\
\text { Misinformation) Erişim Adresi: } \\
\text { https://www.theopennotebook.com/2020/03/02/tipsheet-cove } \\
\text { ring-the-coronavirus-epidemic-effectively-without-spreading } \\
\text {-misinformation/ }\end{array}$ \\
\hline $\begin{array}{lr}\text { Uluslararas1 } & \text { Gazeteciler } \\
\text { Merkezi } & \text { (International } \\
\text { Center for } & \text { Journalists) } \\
\text { öncülüğg̈nde } & \text { kurulan } \\
\text { Uluslararası Gazeteciler Ağ1 }\end{array}$ & $\begin{array}{l}\text { "COVID-19'un Haberleştirilmesinde Etik Hususlar" (Etical } \\
\text { Considerations for Reporting on COVID-19) Erişim Adresi: } \\
\text { https://ijnet.org/en/story/ethical-considerations-reporting-co } \\
\text { vid-19 }\end{array}$ \\
\hline
\end{tabular}

Şekil 4: Sorumlu Haberciliğe Yönelik Çeşitli İlke ve Açıklamalar 


\subsection{Haber Yazımı}

Salgının başından itibaren salgına yönelik enformasyon çok hızlı bir şekilde artmış ve içeriği değişmiştir. Vaka sayıları ve düzeyleri, salgına yönelik politika ve önlemleri içeren protokoller ve yöntemler sürekli bir biçimde değişmeye devam etmektedir. Bu nedenle gazetecilerin halka gerçek riskleri iletebilmesi ve halkın risk algısını kavraması için sürekli bilgi edinmesi gerekmektedir (Pan American Health Organization, 2020a). Gazetecilerin henüz nelerin bilinmediğini açıklaması ve araştırmacıların bilinmeyen şeyleri cevaplamak için çalıştığını söylemesi izler kitlenin kafa karışıklıklarını hafifletebilir (Helmuth, 2020).

Virüse ilişkin gerçekler bağlamsal olarak aktarılmalıdır. Koruyucu önlemler, uygulamalar ve tedavilerden bahsederken "sebeplerin sebepleri" ile birlikte verilmesi ve bağlamsal aktarımlar yapılması insanların sağlık sisteminin nasıl işlediğini, bilimsel yayınların nasıl ortaya çıktığını ve bağışıklık sisteminin nasıl çalıştığını, virüsün vücutta nasıl yayıldığını ve aşıların nasıl üretildiğini öğrenmesini kolaylaştırır (Pan American Health Organization, 2020a: 9, Helmuth, 2020). Haberler koruyucu önlemleri, belirtileri, ne zaman ve nasıl tıbbi yardım alınacağını mutlaka içermelidir. Zaman içerisinde tekrara düşülse bile koruyucu önlemlere yönelik bilgilendirmeler yeniden ve yeniden yapılmalıdır (Pan American Health Organization, 2020a). Farklı toplumsal grupların (dezavantajlı gruplar dâhil) çeşitli senaryolara hazırlanmaları için çeşitli tavsiyelerde bulunulması bireylerin çeşitli konularda hazırlıklı olmalarını kolaylaştırabilecektir (Pan American Health Organization, 2020a).

Haberlerin odaklanması gereken bir diğer husus da toplumun ruh sağlığını korumak ve endişeleri azaltmaktır. Bunun için haberler insanlara ruhsal sağlıklarını korurken ne gibi şeyler yapabilecekleri hakkında bilgiler de içermelidir (Pan American Health Organization, 2020a). Haberlerde korku ve endişeye yol açmak bireylerin ruhsal sağlıklarında çeşitli problemlere yol açabilir. Covid-19'a yönelik önemli tartışmaları iletmek önemli olmakla birlikte, bunu yaparken olay ve olguları dramatize etmekten, krizi abartmaktan kaçınılmalıdır. First Draft'tan Kwan ve ark., gazetecilere “'sonu yok”, "kargaşa”, “felaket” gibi sansasyonel ve yoğun duygu içeren ifade kullanımlarının korku ve paniği arttırabileceği uyarısında bulunmaktadır. Bireylerin hastalığı ve sonuçlarını açık, dürüst ve yapıcı bir şekilde tartışmalarına olanak sağlayacak ve kanıta dayalı bilgiler sunulması gerekir. Gazeteciler, haber kaynaklarını spekülatif veya sansasyonel alıntılar vermeye teşvik etmekten kaçınmalıdır. First Darft'tan gazeteci Wahl Jorgenson'un da belirttiği gibi gazeteciler bilgi sahibi olmadıkları şeyler hakkında açık ve net olmalı ve bildikleri konulara odaklanmalıdır (Kwan ve ark., 2020). 
Haberlerin üretim sürecinin bir diğer boyutu da elde edilen bilginin doğruluğudur. Bu nedenle Pan Amerikan Sağlık Örgütü gazetecilere, gerçeğe dayanan (teyit edilmiş) enformasyonları dolaşıma sokmalarını, aktardıkları bilginin teyit edildiğinden ve resmi kaynaklardan alındığına emin olmalarını tavsiye etmektedir. Ayrıca salgın sürecinde birçok durum, önlem ve tedaviye yönelik kanıtlanmamış enformasyonlar olabilir (Pan American Health Organization, 2020a). Kwan ve ark. (2020), bireylerin arama motorlarında sıkça aradıkları ve merak ettikleri konuları gazetecilerin tespit etmesinin, bu konularla ilgili enformasyon eksikliğinin giderilmesi açısından önemli olduğunu belirtmektedir. Bireylerin kafalarındaki soru işaretlerinin tespit edilmesinde sosyal medya da etkili bir araç olarak kullanılabilir (Helmuth, 2020). Bireylerin merak ettikleri konularda içerik üretilmesi, onların sosyal medya gibi kanallarında yayılan enformasyon bozukluklarından koruma noktasında işlevsel bir rol oynayabilir.

Uluslararası Gazeteciler Ağı (IJNet)'ndan Senami Kojah, Covid-19 salgını boyunca gazeteciler için en önemli sorunun kullandıkları verilerin güvenilirliği meselesi olduğunu belirtmektedir. Salgın süresince vaka sayıları, tıbbi malzemeler için ayrılan fonlar ve virüsün genel olarak yaşama etkisi ile ilgili çok sayıda veri farklı kuruluşlardan ve ülkelerden gelmektedir. Veriler kusurlu olabilir, yanlış sunulabilir, bağlamdan yoksun olabilir ve hatta uydurulmuş olabilir. $\mathrm{Bu}$ nedenle gazetecilerin kapsamlı biçimde sorgulama ve doğrulamayı benimsemesi gerekir. Örneğin 2020 Şubat ayının başlarında Çin'in 1,4 milyar nüfus içerisinde sadece 35 bin vaka varken, tasarlanan bir harita salgının bütün Çin'i sarmış olduğunu göstermektedir. Haberde kümülatif vaka sayılarının kullanılırken koronavirüsün rakamlarını SARS gibi diğer salgınların rakamlarıyla kıyaslamak faydalı olabilir; ancak gerçek zamanlı olarak koronavirüs rakamları henüz düşüş eğiliminde olmadığı için güvenilir olmaz. Birçok insan iyileşmiş, bazıları vefat etmiş ve bazıları tedavi görüyor olduğu için salgının eğilimini ölçmek için kullanılamaz. Gazeteciler, izleyicileri için ortaya koydukları verilerin statik olmamasını ve salgının etkisini küçümsemeden veya abartmadan gerçek zamanlı gelişmeleri izlemek için kullanılabilmesini sağlamak için bu ayrımı yapmalıdır (Kojah, 2020).

Gazetecilerin tedaviler hakkında aktarım yaparken efsanelere veya alternatif tedavi önerilerine (doğal çareler vb.) yer vermekten kaçınması gerektiğini söyleyen Pan Amerikan Sağlık Örgütü, bilim tarafından desteklenmeyen yanlış teorilere yer verilmesinin zararlarına vurgu yapmakta, gerçeğe dayanmayan şeylerin tekrarlandığında doğru olarak algılanabileceğini ve toplumda korku ve endişeye neden olabileceğine dikkat çekmektedir. Söylentiler bir yayımlama filtresinden geçirdikten sonra aktarılmalıdır. First Draft ekibi, çeşitli ortamlarda dolaşan söylentileri aktarmadan önce beş soruya tabi tutulmasını ve bu sorulardan sonra söylentinin 
yayımlanıp yayımlanmayacağına karar verilmesini önermektedir. Bunlar: “(1) Söylenti -herhangi bir platformda- ne kadar ilgi gördü ve bu söylentiye yönelik-geribildirim-sayılarl diğer/benzer içeriklerle yakın düzeyde mi?, (2) Söylentiye ilişkin tartışma sadece belirli bir çevrimiçi toplulukla mı sınırlı? (3) Söylentinin yayılım düzeyi platformları aştı mı? (4) Doğrulanmış veya etki sahibi veya yetkili bir hesap bu söylentiyi paylaştı mı? (5) Büyük medya kuruluşları söylentiyi ele aldı mı?” (2020).

Enformasyon bozuklukları ve söylentiler çürütülürken de dikkat edilmelidir. Örneğin bir söylentiyi tekrar etmek, (gerçeği ortaya çıkarmak için bile olsa) onların daha doğruymuş gibi algılanmalarına sebep olabilir (Helmuth, 2020). Bu nedenle bir söylentiyi tekrar etmekten kaçınmak (özellikle Twitter ve Facebook gibi platformlardaki gönderiler için) daha fazla yayılmasına engel olabilir. First Draft ekibi bu konuda arama motorları ve diğer sosyal paylaşım platformlarında doğrudan söylentiye yönelik anahtar kelime araması yapan okuyuculara yönelik anahtar kelimeler eklenmesini önermektedir. Ayrıca Lakoff' un "Hakikat sandviçi" tekniğiyle önce gerçeğe dayanan enformasyonların, daha sonra söylenti gibi enformasyon bozukluğu unsurlarının verilmesi ve en son tekrar gerçeğe vurgu yapılmasının, -gövde metinini değil de- sadece başlığı veya sadece sosyal medya platformundaki gönderiyi okuyanlar açısından yararlı olacağını belirtmektedir (2020). Helmuth ise bir söylentiyi çürütmenin en iyi yolunun doğrulanmış enformasyonları dolaşıma sokmak olduğunu, özellikle başlıklarda söz konusu mezenformasyonun aslında doğru olmadığını belirtmenin ve içeriğin yanlış olduğu halde neden yayıldığını, insanların buna neden inandığını, bazılarının bunu neden desteklediğini açıklamanın yararlı olacağını ifade etmektedir (2020).

Haberler, damgalamayı ve nefret söylemini körükleyebilmektedir. $\mathrm{Bu}$ nedenle haberlerde hastalığa yakalananlara yönelik etiketlemelerden, stereotip kullanımlardan ve risk grubunda olan kişilerle ilgili ötekileştirebilecek ifadelerden kaçınılmalıdır (Pan American Health Organization, 2020a:8-9, Helmuth, 2020). Örneğin hastalığı “ölümcül” olarak tanımlayan başlıklar insanların paniğe kapılmasına ve aşırı tepki vermesine neden olabilir. "Wuhan virüsü" "Çin virüsü” gibi adlandırmalar kullanmak damgalanmaya yol açar ve ekonomi, ticaret gibi faaliyetlere zarar verebilir. Bu tür olumsuz yargılamalar insanların hastalara karşı olumsuz tavırlar sergilenmesine, bireylerin ayrımcılığa uğramamak için hastalığı gizlemelerine, böylelikle sağlık hizmeti almamalarına ve sağlıklı davranışlar sergilememelerine neden olabilir (Pan American Health Organization, 2020a: 9-10). Uluslararası Gazeteciler Ağı (IJNet)'ndan Senami Kojah da haberlerde nefret söylemi ifadelerinin ve nefret söylemini üretenlerin başlıklarda kullanılmasının onların önemini arttıracağına dikkati çekmektedir. Nefret söylemini 
haberleştirmenin en iyi yolu ona yöneltilen eleştiri ve tepkilerle aktarmaktır. Covid-19 insan hayatına ve hassasiyetlerine mümkün olabildiğince saygı gösterilerek haberleştirilmelidir. Bunların dışında Kojah, vefat sayıları ve son dakika ölüm haberlerinin paylaşılmasında da dikkatli olmayı vurgulamaktadır. Vefat sayılarının insan hayatına duyarlı ve saygı gösteren bir dille açıklanması yanında, son dakika ölüm haberini -bilhassa toplumda ön planda olan biriyse- duyurmadan önce, yerel yetkililer ve polis ile görüşüp ailesinin ve yakınlarının bilgisi olup olmadığını öğrendikten sonra paylaşılması gerekir (Kojah, 2020).

\subsection{Kaynak Kullanımı}

Haberlerin güvenirliği açısından doğru kaynak kullanımı kilit bir öneme sahiptir. Kaynaklar salgında ön saflarda bulunan sağlık çalışanları, bilim insanları, akademisyenler, virologlar, bulaşıcı hastalık uzmanları, genetikçiler, psikologlar, psikiyatristler, antropologlar, iyileşmiş kişiler ve yakınları olabilir. Bu tür uzmanların yanı sıra salgının sosyal ve ekonomik yönlerinin içyüzünü aktarabilecek kişilerden bilgi alınabilir (Pan American Health Organization, 2020a). Bilim insanları ve sağlık hizmeti uygulayıcıları gibi uzmanlardan yapılan alıntılar hem bilgilendirir hem de haberin güvenilirliğini arttırır. Kwan ve ark. (2020) ve Pan American Health Organization (2020a), gazetecilerin okuyucularını sağlık bakanlığı, sağlık otoriteleri veya DSÖ gibi uluslararası sağlık kuruluşları gibi saygın, güvenilir ve resmi kaynaklara yönlendirmesini önermektedir. Böylece okuyucular daha sonra da takip edebilecekleri güvenilir kaynaklardan haberdar olurlar.

First Draft ekibi haberlerde kullanılan araştırmalar konusunda da dikkatli olunması gerektiğini, özellikle henüz tamamlanmamış bazı ön-çalışmaların yararlı olabilirken, bazılarının sahte iddiaları güçlendirebileceğine dikkati çekmektedir. $\mathrm{Bu}$ nedenle bir haberde ön-çalışma kullanılacaksa, muhakkak çalışma ile ilişkisi olmayan bağımsız bir uzmandan veya bilim insanından konu ile görüş alınması gerektiğini ifade etmektedir (Kwan ve ark., 2020). Bilimsel geçerliliği farklı çalışmalarla ispatlanmamış korunma veya çözüm önerileri gibi unsurların medyada dolaşıma girmesi olumsuz sonuçlara neden olabilir. Bu nedenle ön-çalışmalardan edinilen bilgiler dolaşıma konulmadan önce mutlaka teyit edilmelidir.

Gazetecilerin bir diğer rolü de kaynakların kullandığı terminolojiyi anlaşılabilir bir formata dönüştürmek ve kullanılan kavramları açıklamaktır. Laura Helmuth, gazetecilere sağlık terimlerini açıklayan bir sözlük oluşturmalarını önermektedir. Örneğin çoğu insan "topluluk bulaşışı", "asemptomatik bulaşı/yayılma" gibi terimlerin veya karantinanın tam olarak ne anlama geldiğini bilmiyor olabilir ve bu nedenle sağlık terimlerini açıklamak önemlidir (2020). First Draft ekibi de gazetecilere okuyucuların merak ettikleri konular veya arama motorlarında 
aradıkları etiketler üzerine düşünmelerini ve bunlarla ilgili ne gibi içerikler üretildiğine bakmalarını önermektedir (Kwan ve ark., 2020). Benzer şekilde Laura Helmuth da gazetecilerin sosyal medyayı iyi kullanması ve gözlemlemesinin önemine değinirken, örneğin Twitter'da sorular ya da kafa karışıklıkları hakkında güvenilir enformasyon sağlamalarını önermektedir (2020).

Haberlerde yer verilen kaynakların mahremiyet ve gizliliği de bir başka dikkat edilmesi gereken noktadır. Kaynakların haberler nedeni ile damgalamaya maruz kalma riski vardır. $\mathrm{Bu}$ nedenle bazı ülkeler ve kuruluşlar, bu kişilerin özellikle fotoğraf ve videolarını yayımlamak, onlara haberlerde yer vermek için yazılı izin istemektedir (Pan American Health Organization, 2020a). Öte yandan yayımlanan enformasyondan etkilenebilecek kaynaklara, haberde ismine yer verilmesini isteyip istemediği sorulmalıdır. Bazı kaynaklardan ilerleyen süreçlerde enformasyon alabilmek için kaynağın gizliliğinin korunması gerekebilmektedir (Kojah, 2020). Hastalığ́ atlatanlar veya salgın sürecinde toplum yararına çalışan insanlarla ilgili hikâyeler bireylere umut verebilir ve sorunlarla baş etmelerini kolaylaştırabilir.

\subsection{Görsel Kullanımı}

Haberlerde görseller, haritalar, tablolar, infografikler gibi unsurlar karmaşık konuların anlaşılmasını kolaylaştırır. Bununla birlikte Pan Amerikan Sağlık Örgütü fotoğraf kullanırken dikkati olunması gerektiğini, görüntülerin her zaman izleyici üzerindeki etkisini göz önünde bulundurulması gerektiğinin altını çizmektedir (2020a: 8-9). First Draft ekibi de stereotipleri besleyen veya paniğe neden olan hazır görsellerin kullanılmasından kaçınmayı öğütlemektedir (Kwan ve ark., 2020). Bir görsel ya da fotoğrafın anlatılanla ne kadar ilgili olduğu ve anlatının bağlamı göz önünde bulundurulmalıdır. Örneğin maske takan Asyalı bir kişinin fotoğrafını paylaşmadan önce bu fotoğrafın anlatılanlarla ne kadar ilgili olduğunu, hikâyenin konusunun Asyalılar mı, yoksa maskelerin virüsün yayılmasını önlemedeki rolü mü olduğuna karar vermek gerekir. Benzer bir biçimde paniğe neden olabilecek görüntülerden de kaçınılmalıdır. Örneğin tehlikeli madde giysisi giyen kişilerin veya bir evin önünde boş sedye ile bekleyen ambulans görüntüsünün virüsün artan etkisine yönelik endişe oluşturup oluşturmayacağ üzerine düşünülmelidir (Kwan ve ark., 2020).

Başlık ve metin de olduğu gibi görselleştirmeler de korku uyandırmamalıdır. Sadece fotoğraf ve videolarda değil koronavirüse yakalanan birey sayısına ilişkin haritalar ve tablolar konusunda da dikkatli olunmalıdır. Kenneth Field'in "Koronavirüsün Sorumlu Bir Biçimde Haritalandırılması" (Mapping Coronavirus Responsibly) isimli blog yazısı ve First Draft ekibinden Carlotta Dotto ve Jack Berkefeld'in “Koronavirüsten Orman Yangınlarına Dek 
Yanıltıcı Haritalar Gerçeği Çarpıtıyor (From Coronavirüs to Bushfires Misleading Maps are Distorting Reality) başlıklı metni vaka sayıları gibi farklı verilere ev sahipliği yapan haritaların nasıl olması gerektiğine değinmektedir (Kwan ve ark., 2020). Dotto ve Berkefeld (2020); haritaların kim tarafından ve ne amaçla üretildiğine, haritalardaki verilerin nereden geldiğine, ülke ve şehir gibi alanların büyüklüklerinde bir hata olup olmadığına dikkat edilmesi gerektiğini ifade etmektedir. Field (2020) ise haritaların projeksiyon türüne ${ }^{5}$ vurgu yapmakta, bazı projeksiyon türlerinin belirli alanların olması gerektiğinden büyük veya küçük gözükmesine neden olabileceğini ve bu gibi durumların insanların algısını etkileyebileceğini belirtmektedir. Bu noktada farklı haritalar üzerinden yapılan kıyaslamalara dikkat çekilebilir. Örneğin Avrupa ile Amerika kıtaları karşılaştırılırken projeksiyonları ve ölçekleri farklı olan iki harita kullanıldığında bir kıta daha büyük veya daha küçük gözükebilir, yani iki kıtanın gerçekteki kıyaslamalarıyla orantılı olmayabilir, bu durum bireylerin bir kıtada daha fazla vaka olduğu yanılgısına sebep olabilmektedir.

Öte yandan Field, çoğu insanın aşina olduğu -ve gazetecilerin de sıkça yararlandıklar1- "kroplet harita" tekniğine de dikkat çekmekte ve bu tekniğin doğru kullanıldığında işlevsel bir rol oynayabileceğinden, hatalı kullanıldığında ise çeşitli olumsuzluklar doğurabileceğinden söz etmektedir. Kroplet haritalar, birden fazla alana ilişkin verilerin aynı renklerin farklı tonlarıyla veya benzer renkler kullanılarak verilmesini içerir. Kroplet haritalarla toplam vaka sayıları verilmemelidir. Çünkü harita üzerindeki şehir, bölge, ülke gibi alanların yüzölçümleri ve bu yüz ölçümlerinde yaşayan insan sayısı, yani nüfus yoğunluğu eşit değildir (Field, 2020). Örneğin; 700 vakanın olduğu 1 milyon nüfuslu X şehri ile 450 vakanın olduğu 500 bin nüfuslu $\mathrm{Y}$ şehrine ait toplam vaka sayılarının verildiği bir haritada X ilinin daha koyu renkle gösterilmesi hatalı olacaktır. Çünkü X şehrinde nüfusa oranla vaka sayısı $\mathrm{Y}$ iline göre daha azdır ve $\mathrm{Y}$ iline göre $\mathrm{X}$ ili daha açık renkle verilmelidir. Bu nedenle vaka sayıları nüfus gibi çeşitli değişkenlere oranlanarak verilmelidir. Koroplet haritalarlar ilgili olarak göz önünde bulundurulması gereken bir diğer konu da renk seçimidir. Kırmızı gibi tehlike ve ölümü çağrıştıran renkler yerine mavi gibi renkler kullanılmalıdır (Field, 2020).

\section{Sonuç}

Dünya Sağlık Örgütü Genel Direktörü Tedros Adhanom Ghebreyesus'un salgının ilk günlerinde "sadece epidemi ile değil infodemi ile de savaşıyoruz. Sahte haberler virüsten daha

\footnotetext{
5 Harita projeksiyonları, fiziksel yeryüzünün tamamının veya belli bir bölümünün elipsoit veya küre kabul edilerek belli koordinatlar sistemi dahilinde düzlem üzerine çeşitli matematiksel bağıntılar kullanılarak aktarılmasına yarar ve silindirik, konik ve düzlemsel şeklinde sınıflandırılabilir (Yılmaz, 2009: 31-33).
} 
hızlı ve daha kolay yayılıyor ve virüs kadar tehlikeli” sözleriyle salgın döneminde yaygınlaşan enformasyon kirliliğine dikkati çekmiştir. İnsanların çevrelerinden gelen, bilgisine ya da inançlarına katkıda bulunan uyarıcılar olarak tanımlanabilecek olan enformasyon (Visnevath \& Finnegan'dan akt. Çınarlı, 2008: 83) Covid-19 salgını sürecinde de temel bir ihtiyaç olmuştur. Salgın bize sağl1k ile ilgili enformasyonun geniş toplum kesimlerine iletilmesinde kitle iletişim araçlarının birincil kaynak olduğunu göstermiştir. Salgının ilk günlerinde insanların hastalık hakkındaki ilk enformasyon gereksinimleri internette enformasyon aramak olurken, salgının ilerleyen günlerinde haber kuruluşları insanların artan bilgi gereksinimine cevap vermiştir. Ancak bu süreçte de medya aracılığıyla yayılan sağlık enformasyonunun doğru, güvenilir ve kullanılabilir olması daha da önem kazanmıştır.

Salgın doğru, kesin ve ulaşılabilir sağlık enformasyonun öneminin yanında, ayrıca dezenformasyon, mezenformasyon ve yalan haber gibi unsurlarla bağlamından koparılan enformasyonun politik veya ekonomik çıkarlar için nasıl kullanılacağını ve bireylere/toplumlara nasıl zarar verebileceğini de göstermiştir. Covid-19 salgını sürecinde enformasyon bozukluğu sosyal medya aracılığıyla daha geniş kitlelere yayılmış, bireylerin sağlıklarını tehdit eden uygulamaların yaygınlaşmasına, çeşitli birey ve grupların damgalanmaya ve nefret söylemine uğramasına, komplo teorileri nedeniyle gerçeklerden uzaklaşmasına yol açmıştır. Bu durumun önüne geçebilmek için çeşitli gazetecilik ve sağlık kuruluşları tarafından haber medyasına yönelik bazı ilke ve rehberler hazırlanmıştır. Böylece salgın sürecinde neyin haberleştirilip haberleştirilmeyeceği, nasıl haberleştirileceği, kimlerle konuşulacağı, başlığın nasıl atılacağı, görsel unsurların nasıl seçileceği, haber doğrulamanın nasıl yapılacağı gibi sorularda sorumlu habercilik eksenindeki hazırlanan bu rehber ve açıklamalar işlevsel bir biçimde kullanabilir.

Covid-19 sürecinde sorumlu habercilik yapılabilmesi için ortaya konan ilke ve rehberler incelendiğinde -genel bir çerçeveyle- haberin (1) içeriğine, (2) kaynaklarına ve (3) görsellerinin kullanımına dair çeşitli noktalara dikkat çekildiği görülmüştür. Covid-19'a ilişkin haberler, temel olarak gazetecinin çeşitli kaynaklardan elde ettiği verileri ve/veya bilgileri, anlaşılabilir ve kolay tüketilebilir bir formata dönüştürerek sunması sürecidir. Salgın gibi belli bir süre devam eden ve sürekli yeni bilinmezliklerin doğduğu kriz süreçlerinde konu seçimi içeriğin oluşturulmasının ilk aşamasıdır. Gazeteciler bireylerin hali hazırda içerisinde bulunulan durumu anlamalarına ve bu eksende hareket etmelerine yarayacak konuları tespit etmeleri ve bu konularla ilgili bilgi ve/veya enformasyon temin edebilecekleri konulara yönelmeleri gerekmektedir. Bilgiler ve/veya veriler; sağlık alanındaki bürokratik mercilerden sağlık 
uzmanlarına, sağlık uygulayıcılarına ve sosyal medyaya dek birçok kaynaktan elde edilebilmektedir. Pek çok aktör tarafindan üretilen, doğruluk yönü bulunan veya enformasyon bozukluğu kapsamında ele alınan unsurların yoğun biçimde dolaşımda olduğu infodemide, kaynağın güvenilirliği ve verilerin/bilgilerin doğruluğu gazeteciler için önem teşkil etmektedir. Öncelikli olarak başvurulacak/yararlanılacak kaynakların güvenilirliğinin (bununla beraber gerçek bir kişi ise yetkinliğinin) saptanması gerekmektedir. Daha sonra elde edilen verilerin ve/veya bilgilerin işlenmeden (dolayımlanıp haber formatına dönüştürülmeden) önce teyit edilmesi içerik açısından kilit adımlardan birini oluşturmaktadır.

Kaynağın güvenilir (veya yetkin) olduğu saptandıktan ve veriler ve/veya bilgiler teyit edildikten sonra haberin yazım aşaması gelmektedir. Haberlerin birer söylem olması ve söylemlerin bireylerin gerçeklik algılarını oluşturarak aksiyon almalarını etkilemesi, içeriğe kritiklik atfetmektedir. İncelenen açıklama ve rehberlerde haber dilinin sade ve tıbbi jargondan uzak olmasına sıkça atıf yapılmakta, bireylerin haberi kolay bir biçimde anlamasına dikkat çekilmektedir. Sıkça tıbbi terimlerin kullanıldığı, ağdalı dilin hâkim olduğu haberler bireylerin gerçekliği anlamlandırması ve bu eksende aksiyona geçmesinde çeşitli olumsuzluklar yaratabildiği için verilmek istenenler sade bir dille net bir biçimde ortaya konulmalıdır. Akabinde sözcük seçimleri de önem arz etmektedir. Bireyleri korku ve endişeye sevk edecek veya aksi biçimde mevcut tehlikenin önemini azaltacak ya da belli bir kişiyi-grubu damgalayacak, nefret söylemine sevk edecek sözcüklerin ve üslubun gerek başlıklarda gerek gövde metinde kullanılmamasına vurgu yapılmaktadır. Öte yandan görseller, haberlerde dikkat çeken ve kolay algılanan öğelerdir. Bu nedenle sözlük seçimi ve üslup kullanımında olduğu gibi; fotoğraflar, videolar, infografikler ve virüse ilişkin haritalar dikkatle seçilmelidir.

Sorumlu haberciliğe ilişkin ilke ve açıklamalar, infodeminin etkili olduğu medya ekosisteminde ve Covid-19 salgınında haberciler için önemli bir rota sunmaktadır. Toplumsal yararı önceliği haline getiren bu ilke ve açıklamaların haber medyasında ne denli etkin kullanıldığına yönelik analizler içeren çalışmaların yapılması konuya yönelik kapsamlı verilerin ortaya konmasına ve geliştirilmesine, haber örnekleri üzerinden örneklendirmeler yapan çalışmaların yapılması ise söz konusu ilkelerin daha kolay kavranmasına önayak olabilir.

\section{Kaynakça}

Allcott, Hunt ve Gentzkow, Matthew (2017), "Social Media and Fake News in the 2016 Election”, Journal of Economic Perspectives, 31(2), p. 211-236. 
Akyüz, Selman Selim (2020), “Yanlış Bilgi Salgını: COVID-19 Salgını Döneminde Türkiye'de Dolaşıma Giren Sahte Haberler”, Akdeniz Üniversitesi İletişim Fakültesi Dergisi, 34, s. 422-444.

Baines, Darrin and Elliott, Robert (2020), "Defining Misinformation, Disinformation and Malinformation: an Urgent Need for Clarity During the COVID-19 İnfodemic", Discussion Papers 20-06, Department of Economics, University of Birmingham, http://www.repec.bham.ac.uk/pdf/20-06.pdf, Erişim Tarihi: 19.03.2021.

Berger, Guy (2018), Foreword, (Editors), Cherilyn Ireton and Julie Posetti. Journalism, 'Fake News' \& Disinformation, Paris: Unesco, p. 7-13, https://en.unesco.org/sites/default/files/journalism_fake_news_disinformation_print_fr iendly_0.pdf Erişim Tarihi: 10.03.2021.

Çağlar, Şebnem (t.y), “Televizyon Haberciliği Ders Notu”, İstanbul Üniversitesi Açık ve Uzaktan Eğitim Fakültesi, http://auzefkitap.istanbul.edu.tr/kitap/kok/televizyon_gazateciligi_u136.pdf, Erişim Tarihi: 03.03.2021.

Çınarlı, İnci (2008), Sağlık İletişimi ve Medya, Nobel Yayıncılık, Ankara.

Demir, Demirhan Hanifi ve Balc1, Emre Vadi (2019), “Kriz Haberciliği ve Etik Sorunsalı”, Ege Üniversitesi İletişim Fakültesi Yeni Düşünceler Hakemli E-Dergisi, 11, s. 48-56.

Dotto, Carlotta and Berkefeld, Jack (2020, 27 February), From Coronavirus to Bushfires Misleading Maps are Distorting Reality, First Draft, https://firstdraftnews.org/latest/from-coronavirus-to-bushfires-misleading-maps-are-di storting-reality/, Erişim Tarihi: 27.04.2021.

Ertem, Melike (2020), “COVID-19 Pandemisi ve Sosyal Damgalama”, İzmir Katip Çelebi Üniversitesi Sağlık Bilimleri Fakültesi Dergisi, 5 (2), s. 135-138.

Eysenbach, Gunther (2002), "Infodemiology: The Epidemiology of (Mis) Information”, The American Journal of Medicine, 113(9), p. 763-765.

Eysenbach, Gunther (2020), "How to Fight an Infodemic: The Four Pillars of Infodemic Management", Journal of Medical Internet Research, 22(6), e21820.

Fetzer, James Henry (2004), “Information: Does It Have to Be True?" Minds and Machines, 14, p. 223-229. 
Field, Kenneth (2020, 25 February), Mapping Coronavirus Responsibly, Esri, https://www.esri.com/arcgis-blog/products/product/mapping/mapping-coronavirus-res ponsibly/, Erişim Tarihi: 27.04.2021.

Fletcher, Richard, Kalogeropoulos, Antonis, Simon, Felix, and Nielsen, Rasmus Kleis (2020), Information Inequality in the UK Coronavirus Communications Crisis, Reuters Institute for the Study of Journalism, https://reutersinstitute.politics.ox.ac.uk/sites/default/files/2020-07/Fletcher_et_al_Infor mation Inequality FINAL.pdf, Erişim Tarihi: 06.03.2021.

Helmuth, Laura (2020), Tipsheet: Covering the Coronavirus Epidemic Effectively without Spreading Misinformation, The Open Notebook, https://www.theopennotebook.com/2020/03/02/tipsheet-covering-the-coronavirus-epid emic-effectively-without-spreading-misinformation/, Erişim Tarihi: 21.03.2021.

İnceoğlu, Yasemin (2020), “Covid-19 Pandemisi ve Medya”, TTB Covid-19 Pandemisi 6. Ay Değerlendirme Raporu, s. 632-643.

Islam, Md Saiful, Sarkar, Tonmoy, Khan, Sazzad Hossain, Kamal, Abu-Hena Mostofa, Hasan, Murshid, Kabir, Alamgir, Yeasmin, Daila, Islam, Mohammad Ariful, Chowdhury, Kamal Ibne Amin, Anwar, Kazi Selim, Chughtai, Abrar Ahmad and Seale, Holly (2020), "COVID-19-Related İnfodemic and Its Impact on Public Health: A Global Social Media Analysis", The American Journal of Tropical Medicine and Hygiene, 103(4), p. 1621-1629.

Karlova, Natascha and Fisher, Karen (2012), "Plz RT: A Social Diffusion Model of Misinformation and Disinformation for Understanding Human Information Behaviour", Proceedings of the ISIC2012, Tokyo, 1-17, https://www.hastac.org/sites/default/files/documents/karlova_12 isic_misdismodel.pd f, Erişim Tarihi: 24.02.2021.

Kojah, Senami (2020), Etichal Considerations for Reporting on COVID-19, International Journalism Network, https://ijnet.org/en/story/ethical-considerations-reporting-covid-19, Erişim Tarihi: 28.03.2021.

Klein, David and Wueller, Joshua (2017), "Fake News: A Legal Perspective", Journal of Internet Law, 20(10), p. 6-13. 
Kwan, Victoria (2019), "First Draft's Essential Guide to Responsible Reporting in An Age of Information Disorder", First Draft, https://firstdraftnews.org/wp-content/uploads/2019/10/Responsible_Reporting_Digital AW-1.pdf?x82677, Erişim Tarihi: 23.03.2021.

Kwan, Victoria, Wardle, Claire and Webb, Madelyn (2020), Tips for Reporting on Covid-19 and Slowing the Spread of Misinformation, First Draft, https://firstdraftnews.org/latest/tips-for-reporting-on-covid-19-coronavirus-and-slowi ng-the-spread-of-misinformation/, Erişim Tarihi: 18.03.2021.

Lazer, David, Baum, Matthew, Benkler, Yochai, Berinsky, Adam, Greenhill, Kelly, Menczer, Fillippo, Metzger, Miriam, Nyhan, Brendan, Pennycook, Gordon, Rothschild, David, Schudson, Michael, Sloman, Steven, Sunsteini Cass, Thorson, Emily, Watts, Duncan, Zittrain, Jonathan (2018), "The science of fake news", Science, 359(6380), p. 1094-1096.

Nielsen, Rasmus Kleis, Fletcher, Richard, Newman, Nic, Brennen, Scott and Howard, Philip (2020a), Navigating the 'Infodemic': How People in Six Countries Access and Rate News and Information about Coronavirus, Reuters Institute for the Study of Journalism, https://reutersinstitute.politics.ox.ac.uk/sites/default/files/2020-04/Navigating\%20the \%20Coronavirus\%20Infodemic\%20FINAL.pdf, Erişim Tarihi: 25.02.2021.

Nielsen, Rasmus Kleis, Kalogeropoulos, Aantonios and Fletcher, Richard (2020b), Social Media Very Widely Used but Use for News and Information about COVID-19 is Declining, Reuters Institute for the Study of Journalism, https://reutersinstitute.politics.ox.ac.uk/sites/default/files/2020-06/UK\%20COVID-19 $\% 20$ News $\% 20$ and\%20Information\%20Factsheet\%206\%20FINAL.pdf, Erişim Tarihi: 22.02.2021.

Pan American Health Organization (2020a), COVID-19 An Informative Guide: Advise for Journalists, https://iris.paho.org/bitstream/handle/10665.2/52392/PAHOCMUPACOVID-1920003 eng.pdf?sequence=1\&isAllowed=y, Erişim Tarihi: 12.04.2021.

Pan American Health Organization (2020b), Understanding the Infodemic and Misinformation in the Fight Againist Covid-19, Factsheet N.5, 
https://iris.paho.org/bitstream/handle/10665.2/52052/Factsheet-infodemic_eng.pdf?seq

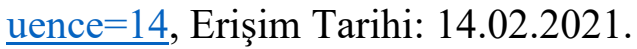

Santos-D'amorim, K. and de Oliveira MIRANDA, M. K. F. (2021), "Misinformation, Disinformation and Malinformation: Clarifying the Definitions And Examples in Disinfodemic Times", Encontros Bibli: Revista Eletrônica de Biblioteconomia E Ciência da Informação, 26, p. 01-23.

Silsüpür, Sinan (2018, Aralık 14), Bilgi Bozukluğunu Anlamak İçin Kavramlar, Teyit.org. https://teyit.org/bilgi-bozuklugunu-anlamak-icin-kavramlar/, Erişim Tarihi: 02.03 .2021 .

Straus, Sharon, Tetroe, Jacqueline and Graham, Ian (2009), "Defining Knowledge Translation”, CMAJ, 181(3-4), p. 165-168.

Sudsawad, Pimjai (2007), "Knowledge Translation: Introduction to Models, Strategies and Measures", Austin, TX: Southwest Educational Development Laboratory, National Center for the Dissemination of Disability Research.

Tangcharoensathien, Viroj, Calleja, Neville, Nguyen, Tim, Purnat, Tina, D’Agostino, Marcelo, Garcia-Saiso, Sebastian, Landry, Mark, Rashidian, Arash, Hamilton, Clayton, AbdAllah, Abdelhalim, Ghia, Ioana, Hill, Alexandra, Hougendobler, Daniel, van Andel, Judith, Nunn, Mark, Brooks, Ian, Sacco, Pier Luigi, de Domenico, Manlio, Mai, Philip, Gruzd, Anatoliy, Alaphilippe, Alexandre, Briand, Sylvie (2020), "Framework For Managing the COVID-19 Infodemic: Methods and Results of an Online Crowdsourced WHO Technical Consultation", Journal of Medical Internet Research, 22(6), e19659.

Taylan, Ahmet ve Ünal, Recep (2017), “Ana Akım Medyada Sansasyonel Habercilik: Sağlık İletişimi Örneği”,, Atatürk İletişim Dergisi, 14, p. 27-44.

Ulmer, Robert, Sellnow, Timothy and Seeger, Matthew (2009), Post-Crisis Communications and Renewal: Understanding the Potential for Positive Outcomes in Crisis Communication, (Editors), Robert L. Heath and H. Dan O'Hair. Handbook of Risk and Crisis Communication. Routledge, p. 302-322.

Uzun, Ruhdan (2020), Sahte Haber Oksimoronu Işı̆̆ında Değişen Haber Ortamını Yeniden Düşünmek, (Derleyenler), Özlem Erkmen, Bora Ataman, Barış Çoban. Yeni Gazetecilik: Mecralar, Deneyimler Olanaklar, İstanbul Kafka, s.53-81. 
Uzunoğlu, Sarphan ve Uyar, Verda (2021), Türkiye'de Doğru Bilgiyi Aramak: Çöldeki Vahanın Peşinde, Newslab Turkey, https://www.newslabturkey.org/wp-content/uploads/2021/04/rh-2.pdf, Erişim Tarihi: 18.04.2021.

Wardle, Claire (2019a), First Draft's Essential Guide to Understanding Information Disorder, https://firstdraftnews.org/wp-content/uploads/2019/10/Information_Disorder_Digital_ AW.pdf?x41166, Erişim Tarihi: 26.02.2021.

Wardle, Claire (2019b), Information Disorder: The Techniques We Saw in 2016 Have Evolved, First Draft, https:/firstdraftnews.org/latest/information-disorder-the-techniques-we-saw-in-2016-h ave-evolved/, Erişim Tarihi: 02.03.2021.

Wardle, Claire and Derakhshan, Hossein (2018), Thinking About Information Disorder: Formats of Misinformation, Disinformation and Mal-Information, (Editors), Cherilyn Ireton and Julie Posetti. Journalism, 'fake news' \& disinformation. Paris: UNESCO, 43-54,

https://en.unesco.org/sites/default/files/journalism_fake_news_disinformation_print_fr iendly 0.pdf, Erişim Tarihi: 16.02.2021.

World Health Organization (2020a, September 23), Managing the COVID-19 Infodemic: Promoting Healthy Behaviours and Mitigating the Harm from Misinformation and Disinformation,

https:/www.who.int/news/item/23-09-2020-managing-the-covid-19-infodemic-promo ting-healthy-behaviours-and-mitigating-the-harm-from-misinformation-and-disinform ation, Erişim Tarihi: 17.01.2021.

World Health Organization (2020b, February 15), Munih Securiyt Conference, https://www.who.int/director-general/speeches/detail/munich-security-conference, Erişim Tarihi: 25.01.2021.

World Health Organization (2020c, October 21), Let's Flatten the Infodemic Curve, https://www.who.int/news-room/spotlight/let-s-flatten-the-infodemic-curve, Erişim Tarihi: 26.01.2021.

Yılmaz İbrahim (2009), “Uygun Harita Projeksiyonu Seçiminde Bazı Temel Esaslar”, Harita Teknolojileri Elektronik Dergisi, 1(2), p. 31-42. 